Jurnal Ilmu Ilmu Agribisnis: Journal of Agribusiness Science, 9(4), November 2021

\title{
PENENTUAN HARGA POKOK PENJUALAN USAHA PENGGEMUKAN SAPI POTONG MITRA DAN NON-MITRA DI DESA ASTOMULYO KECAMATAN PUNGGUR KABUPATEN LAMPUNG TENGAH
}

\author{
(Selling Main Cost Determination Between Partner and Non-partner Cattle Fattening Business \\ in Astomulyo Village Punggur Subdistrict of Central Lampung Regency)
}

Novalia, Raden Hanung Ismono, Adia Nugraha

\begin{abstract}
Jurusan Agribisnis, Fakultas Pertanian, Universitas Lampung, Jl. Prof. Dr. Soemantri Brojonegoro No. 1 Bandar Lampung 35145, e-mail: hanung.ismono@fp.unila.ac.id
\end{abstract}

\begin{abstract}
This research aims to find out production main cost, selling main cost, and the differences of production main cost and selling main cost between partner and non-partner cattle fattening business. Furthermore, this research uses cencus method which is conducted on cattle fattening in Astomulyo Village, Punggur Subdistrict, Central Lampung Regency. The location are chosen purposively as the consideration that the Punggur Sub-district, Central Lampung Regency has the largest cattle population in Lampung Province. Data in this research are analyzed using production main cost, selling main cost and independent sample test. The result shows that: the production main cost of cattle fattening partner and non-partner is $R p 39,119.17 / \mathrm{kg}$ and Rp40,552.24/kg, respectively. Then, the selling main cost of cattle fattening partner and non-partner is Rp39,763.90/kg and Rp40,736.12/kg, respectively. Finally, there is a significant difference in the production main cost and the selling main cost between partner and non-partner cattle fattening business.
\end{abstract}

Key words: cattle fattening, production main cost, selling main cost

Received: 6 July 2020 Revised:6 August 2020 Accepted:27 August $2020 \quad$ DOI: http://dx.doi.org/10.23960/jiia.v9i4.5399

\section{PENDAHULUAN}

Sektor pertanian merupakan salah satu sektor yang berperan dalam perkembangan perekonomian di Indonesia. Pengembangan sektor pertanian dapat dilakukan melalui berbagai macam subsektor yaitu subsektor tanaman pangan, subsektor peternakan, subsektor perikanan, subsektor perkebunan, dan subsektor kehutanan. Subsektor peternakan kini menjadi subsektor yang strategis dalam upaya mencapai ketahanan pangan nasional, peningkatan gizi masyarakat dan penyerapan tenaga kerja. Namun, hal tersebut harus dicapai dengan menghadapi tantangan yang cukup banyak, diantaranya ancaman produk impor, penurunan mutu bibit ternak besar dan ketergantungan pakan ternak impor.

Salah satu upaya untuk memperluas pengembangan subsektor peternakan adalah beternak sapi. Sapi potong merupakan hewan ternak yang dapat menopang kebutuhan konsumsi daging, karena sapi dapat diternakkan secara sederhana, mudah, disukai banyak kalangan masyarakat dan tubuhnya cukup besar apabila dibandingkan dengan ternak lain (Yulianto dan Saparinto 2010).

Populasi ternak sapi potong terus mengalami peningkatan tiap tahunnya. Secara rata-rata peningkatan sapi potong tiap tahunnya adalah sebanyak 935.716 ekor/tahun atau sebesar 6,809 persen/tahun. Menurut BPS (2018) bahwa di Indonesia terjadi peningkatan volume impor daging sapi terus menerus dari tahun 2013-2017. Pemerintah mengharapkan dengan melakukan impor daging sapi dapat memenuhi kebutuhan permintaan daging sapi, tetapi pada kenyataannya hanya membuat para pemilik usaha penggemukan sapi tidak bersemangat untuk melanjutkan usahanya karena harga jual sapi potong cenderung menurun.

Volume impor sapi yang mengalami fluktuasi, jumlahnya sangat tinggi jika dibandingkan dengan volume impor hewan ternak lainnya. Hal ini menggambarkan bahwa produksi sapi di Indonesia masih rendah dan belum cukup untuk memenuhi permintaan sapi oleh masyarakat di Indonesia. Provinsi Lampung merupakan salah satu sentra ternak sapi potong, sehingga sapi 
potong merupakan komoditas utama dalam peternakan untuk mendorong potensi pengembangan peternakan secara keseluruhan. Angka populasi ternak sapi potong di Kabupaten Lampung Tengah terus mengalami kenaikan dari tahun 2014-2017. Rata-rata peningkatan sapi potong di Kabupaten Lampung Tengah tiap tahunnya meningkat sebanyak 37.894 ekor per tahun atau sebesar 33,53 persen per tahun. Kabupaten Lampung Tengah mampu memenuhi kebutuhan sapi potong di Provinsi Lampung sebesar 39,20 persen dari jumlah keseluruhan kebutuhan sapi potong di Provinsi Lampung.

Rata-rata populasi ternak sapi pada tahun 20132017 di Kecamatan Punggur cenderung menurun sebanyak 159 ekor per tahun atau sebesar 4,69 persen per tahun. Kecamatan Punggur memiliki 9 desa dan masing-masing desa mengusahakan ternak sapi. Desa Astomulyo merupakan desa yang menjadi sentra ternak sapi terbesar di Kecamatan Punggur. Hal ini ditunjukkan melalui populasi ternak sapi yang semakin meningkat setiap tahunnya dan jumlah populasi ternak sapi yang paling tinggi di antara desa yang lainnya.

Populasi ternak sapi potong di Desa Astomulyo selalu mengalami kenaikan dari tahun 2014-2017. Rata-rata peningkatan populasi sebanyak 56 ekor per tahun atau sebesar 7,06 persen per tahun. Desa Astomulyo memiliki dua kelompok ternak yaitu Kelompok Ternak Limousin dan Kelompok Ternak Cempaka. Peternak sapi potong yang tergabung dalam Kelompok Ternak Limousin sebagian besar melakukan mitra dengan PT GGL (PT. Great Giant Livestock), namun ada juga peternak yang tidak melakukan mitra.

Kemitraan di Kelompok Ternak Limousin dilakukan dengan mitra PT. GGL. Peran PT GGL menyediakan pakan ternak berupa pakan konsentrat dan kulit buah nanas dalam bentuk silase yang diperoleh dari limbah PT. Great Giant Foods (PT GGF). Ketika bobot sapi sudah masuk dalam kriteria yang diinginkan oleh PT GGL, maka sapi tersebut akan dijual dengan persetujuan PT GGL.

Harga pakan yang tinggi dengan harga output yang relatif rendah menjadi permasalahan untuk peternak sapi potong, hal ini membuat peternak harus menghitung ulang biaya yang dikeluarkan untuk memproduksi sapi potong. Perkembangan harga produsen sapi potong di tingkat peternak pada tahun 2014-2018 di Provinsi Lampung mengalami fluktuasi. Fluktuasi harga disebabkan oleh banyaknya daging sapi impor yang masuk ke Provinsi Lampung yang mengakibatkan persaingan harga. Adanya kebijakan impor daging yang dibuat pemerintah akan membuat harga jual di tingkat produsen cenderung merosot.

Perhitungan harga pokok produksi perlu dilakukan untuk mengetahui berapa biaya yang dikeluarkan oleh peternak selama melakukan kegiatan penggemukan sehingga peternak mengetahui apakah harga yang diterima atas penjualan hasil panennya itu menguntungkan atau tidak. Penetapan harga pokok penjualan sapi potong menjadi sangat penting bagi peternak, karena harga merupakan salah satu penentu keberhasilan suatu usaha yang akan menentukan seberapa besar keuntungan yang diperoleh petani atas penjualan produknya. Berdasarkan uraian sebelumnya, maka tujuan penelitian ini adalah untuk menganalisis harga pokok produksi, harga pokok penjualan dan menganalisis perbedaan harga pokok produksi dan harga pokok penjualan antara usaha penggemukan sapi potong mitra dengan non-mitra di Desa Astomulyo Kecamatan Punggur Kabupaten Lampung Tengah.

\section{METODE PENELITIAN}

Metode penelitian yang digunakan adalah studi kasus. Penelitian dilakukan di Desa Astomulyo Kecamatan Punggur Kabupaten Lampung Tengah. Penentuan lokasi penelitian dilakukan secara sengaja (purposive) dengan pertimbangan bahwa Kecamatan Punggur merupakan sentra produksi sapi potong yang memiliki kelompok ternak sapi potong. Pengambilan data dilakukan pada Bulan November 2019 - Januari 2020. Responden penelitian ini berada di Dusun I di Desa Astomulyo sebanyak 61 peternak yang terdiri dari 52 peternak mitra dan 9 peternak non mitra.

Data yang digunakan adalah data primer dan sekunder. Data primer diperoleh dari wawancara menggunakan kuesioner, serta pengamatan langsung tentang keadaan di lapangan seperti data nama anggota Kelompok Ternak Limousin, data harga bakalan sapi, data harga pakan, vitamin dan obat-obatan dalam usaha penggemukan sapi potong. Data sekunder diperoleh dari lembaga atau instansi terkait, seperti Kementrian Pertanian Indonesia, BPS Provinsi Lampung, BPP Kecamatan Punggur dan Dinas Peternakan dan Perikanan Kabupaten Lampung Tengah seperti data populasi sapi potong di Indonesia, Provinsi 
Lampung, Kabupaten Lampung Tengah, Kecamatan Punggur dan Desa Astomulyo. Metode analisis data yang digunakan pada penelitian ini adalah metode analisis deskriptif kuantitatif. Analisis deskriptif kuantitatif digunakan untuk menganalisis harga pokok produksi dan harga pokok penjualan.

Analisis harga pokok produksi digunakan untuk menjawab tujuan pertama. Perhitungan harga pokok produksi pada penelitian ini dilakukan dengan menggunakan rumus Kartadinata (2000):

Rumus perhitungan harga pokok produksi

Biaya bahan langsung Rp xxx

Biaya tenaga kerja langsung $\quad \mathrm{Rp} x \mathrm{xx}$

Biaya tidak langsung tetap $\mathrm{Rp} x \mathrm{xx}$

Biaya tidak langsung variabel $\mathrm{Rp} \underline{\mathrm{xxx}+}$

Harga pokok produksi $\mathrm{Rp} \mathrm{xxx}$

Analisis yang digunakan untuk menjawab tujuan kedua yaitu analisis harga pokok penjualan. Menurut Adikoesoemah (1982), harga pokok penjualan menjumlahkan harga pokok produksi, biaya-biaya penjualan dan biaya-biaya administrasi dan umum. Analisis harga pokok penjualan usaha penggemukan sapi potong dapat dihitung dengan menggunakan rumus sebagai berikut :

Rumus perhitungan harga pokok penjualan

$\begin{array}{ll}\text { Harga pokok produksi } & \mathrm{Rp} \mathrm{xxx} \\ \text { Biaya-biaya penjualan } & \mathrm{Rp} \mathrm{xxx} \\ \text { Biaya-biaya administrasi dan umum } & \mathrm{Rp} \mathrm{xxx}+ \\ \text { Harga pokok penjualan } & \mathrm{Rp} \mathrm{xxx}\end{array}$

Analisis yang digunakan untuk menjawab tujuan ketiga adalah dengan uji beda (Independent Samples Test) menggunakan SPSS untuk melihat adakah perbedaan yang signifikan antara harga pokok produksi dan harga pokok penjualan usaha penggemukan sapi potong mitra dengan usaha penggemukan sapi potong non mitra.

Hipotesis yang digunakan dalam penelitian ini adalah sebagai berikut:

$\mathrm{H}_{0}: \mathrm{m}_{1}=\mathrm{m}_{2}$ (Tidak ada perbedaan harga pokok produksi dan harga pokok penjualan antara usaha penggemukan sapi potong mitra dengan usaha penggemukan sapi non mitra).

$\mathrm{H}_{1}: \mathrm{m}_{1} \neq \mathrm{m}_{2}$ (Ada perbedaan harga pokok produksi dan harga pokok penjualan antara usaha penggemukan sapi potong mitra dengan usaha penggemukan sapi non mitra.)
Kriteria pengambilan keputusan adalah sebagai berikut :

a. Jika nilai sig (2-tailed) $>0,05$ maka terima $\mathrm{H}_{0}$, artinya tidak ada perbedaan harga pokok produksi dan harga pokok penjualan antarausaha penggemukan sapi potong mitra dengan usaha penggemukan sapi non mitra.

b. Jika nilai sig (2-tailed) $<0,05$ maka tolak $\mathrm{H}_{0}$, artinya ada perbedaan harga pokok produksi dan harga pokok penjualan antara usaha penggemukan sapi potong mitra dengan usaha penggemukan sapi non mitra.

\section{HASIL DAN PEMBAHASAN}

\section{Karakteristik Peternak Responden}

Sebanyak 21,15 persen umur responden peternak mitra dan sebanyak 33,33 persen umur responden peternak non mitra berada di kelompok umur 43 49 tahun dan 44,23 persen untuk responden peternak mitra dan sebanyak 66,67 persen untuk responden peternak non mitra menempuh tingkat pendidikan hingga jenjang sekolah menengah atas (SMA). Mayoritas petani nanas memiliki jumlah tanggungan keluarga sebanyak $3-4$ orang sebanyak 57,69 persen untuk peternak mitra dan 66,67 persen untuk peternak non mitra, memiliki pengalaman beternak sebanyak 51,92 persen untuk peternak mitra dan sebanyak 4 peternak dan 44,44 persen untuk peternak non mitra dan memperoleh sumber dana tunai dari pinjaman bank sebanyak 90,38 persen untuk peternak mitra dan sebanyak 4 peternak dan 77,78 persen untuk peternak non mitra.

\section{Kegiatan Usaha Ternak Sapi Potong Mitra dan Non-mitra}

Kegiatan yang sama-sama dilakukan oleh usaha penggemukan sapi potong mitra dan non-mitra adalah pemberian pakan, pemeliharaan kandang, pengendalian penyakit dan vaksinasi dan pemasaran. Pemberian pakan dilakukan secara rutin setiap pagi dan sore. Pakan utama yang diberikan oleh peternak responden ada tiga macam, yaitu kulit singkong, kulit nanas, dan onggok. Agar nutrisi dan vitamin dalam tubuh sapi terjaga, maka diberi pakan tambahan berupa konsentrat Pemeliharaan kandang dilakukan setiap hari agar sapi tidak mudah terkena penyakit. Kandang dibersihkan dengan menggunakan sapu lidi dan dialirkan menggunakan air.

Pengontrolan kesehatan dilakukan setiap pagi hari setelah pemberian pakan. Apabila sapi terkena 
penyakit cacing, peternak akan memberi obat dengan merk Kalbazen yang diperoleh dengan harga Rp100.000,00 sampai dengan Rp115.000,00 per botol (berisi $500 \mathrm{ml}$ ), penyakit kulit yaitu merk Invervet dengan harga Rp160.000,00 sampai dengan Rp185.000,00 per botol (berisi $100 \mathrm{ml}$ ), penyakit demam yaitu merk Sulpidon dengan harga Rp50.000,00 sampai dengan Rp65.000,00 per botol (berisi $100 \mathrm{ml}$ ) dan penyakit kaki pincang yaitu merk Penstrep dengan harga Rp100.000,00 per botol (berisi $100 \mathrm{ml}$ ) sampai dengan Rp110.000,00 per botol (berisi $100 \mathrm{ml}$ ).

Usaha penggemukan sapi potong mitra dan nonmitra tidak mengalami kesulitan dalam proses penjualan, karena sudah memiliki pelanggan diantaranya yang berasal dari Padang, Bangka, Palembang, Jakarta dan Medan yang memiliki tangan kanan di Lampung untuk memudahkan proses pembelian sapi potong. Kegiatan usaha penggemukan sapi potong mitra dan non-mitra sama, hanya terdapat perbedaan pada biaya bahan tidak langsung berupa pakan, vitamin dan obatobatan.

\section{Biaya Produksi}

Perhitungan biaya pada penelitian ini didasarkan pengklasifikasian biaya berdasarkan proses produksi selama satu periode (6 bulan) dalam usaha penggemukan sapi potong. Komponen biaya yang dihitung untuk memperoleh harga pokok produksi adalah biaya bahan langsung, biaya tenaga kerja langsung, biaya tidak langsung variabel dan biaya tidak langsung tetap.

\section{Biaya bahan langsung}

Bakalan sapi merupakan salah satu faktor penting yang digunakan untuk melakukan kegiatan usaha ternak sapi. Syarat-syarat tersebut dibuat dengan pertimbangan sapi tersebut sudah siap untuk digemukkan, dengan postur tubuh yang kuat sapi dianggap mampu untuk menopang badannya apabila sudah memiliki berat yang diinginkan oleh peternak. Rata-rata jumlah sapi yang dipelihara oleh usaha penggemukan sapi potong mitra sebanyak 5 ekor dan non-mitra sebanyak 6 ekor. Total biaya yang dikeluarkan peternak untuk membeli bakalan sapi selama satu periode dapat dilihat pada Tabel 1 .

\section{Biaya tenaga kerja langsung}

Tenaga kerja langsung pada usaha penggemukan sapi potong adalah tenaga kerja yang terlibat langsung dalam kegiatan penggemukan sapi potong. Total biaya tenaga kerja langsung pada usaha penggemukan sapi potong mitra dan non mitra dapat dilihat pada Tabel 1 .

Tabel 1 menunjukkan total biaya langsung yang dikeluarkan oleh usaha penggemukan sapi potong mitra dan non mitra. Total biaya yang dikeluarkan oleh usaha penggemukan sapi potong mitra untuk bahan langsung (bakalan sapi) dalam satu periode adalah sebesar Rp15.324.769,23 per ekor, sedangkan usaha penggemukan sapi potong non mitra adalah sebesar Rp17.492.733,56 per ekor.

Total biaya yang dikeluarkan oleh usaha penggemukan sapi potong mitra untuk membayar tenaga kerja langsung adalah sebesar Rp603.139,19 dan non mitra sebesar Rp571.991,64 dalam satu periode. Hal ini menunjukkan bahwa total biaya yang dikeluarkan oleh usaha penggemukan sapi potong non-mitra untuk membayar biaya bahan langsung per periode lebih tinggi sebesar 14,14 persen daripada usaha penggemukan sapi potong mitra karena pada pembelian bakalan sapi untuk bobot awal usaha penggemukan sapi potong mitra sesuai dengan kriteria yang telah ditetapkan oleh PT. GGL dengan bobot kisaran 300 kilogram, sehingga bobot awal bakalan sapi usaha penggemukan sapi potong non-mitra lebih berat dengan kisaran 400 kilogram.

\section{Biaya tidak langsung variabel}

\section{Biaya bahan tidak langsung}

Biaya bahan tidak langsung merupakan biaya yang digunakan sebagai bahan penolong dalam usaha penggemukan sapi. Biaya bahan tidak langsung usaha penggemukan sapi terdiri dari pakan, vitamin dan obat-obatan.

Tabel 1. Biaya langsung usaha penggemukan sapi potong mitra dan non mitra dalam satu periode

\begin{tabular}{lcc}
\hline \multirow{1}{*}{ Biaya Langsung } & \multicolumn{1}{c}{ Mitra } & Non Mitra \\
\cline { 2 - 3 } & $\begin{array}{c}\text { Biaya } \\
\text { (Rp/periode) }\end{array}$ & $\begin{array}{c}\text { Biaya } \\
\text { (Rp/periode) }\end{array}$ \\
\hline $\begin{array}{l}\text { Biaya Bahan Langsung } \\
\text { Biaya Tenaga Kerja } \\
\text { Langsung }\end{array}$ & $15.324 .769,23$ & $17.492 .733,56$ \\
\hline
\end{tabular}


Tabel 2. Biaya tidak langsung variabel pada usaha penggemukan sapi potong mitra dan non mitra dalam satu periode

\begin{tabular}{lrr}
\hline $\begin{array}{l}\text { Biaya Tidak Langsung } \\
\text { Variabel }\end{array}$ & \multicolumn{1}{c}{ Mitra } & \multicolumn{1}{c}{ Non Mitra } \\
\cline { 2 - 3 } & $\begin{array}{c}\text { Biaya } \\
\text { (Rp/periode) }\end{array}$ & $\begin{array}{c}\text { Biaya } \\
\text { (Rp/periode) }\end{array}$ \\
\hline Biaya Bahan Tidak & & \\
Langsung & $4.401 .272,46$ & $4.255 .580,17$ \\
Biaya Lain-lain & $102.893,78$ & $96.116,88$ \\
$\begin{array}{l}\text { Biaya Tenaga Kerja Tak } \\
\text { Langsung }\end{array}$ & $11.355,31$ & $9.611,69$ \\
\hline
\end{tabular}

Pakan yang digunakan adalah kulit singkong, kulit nanas, onggok dan konsentrat. Vitamin yang digunakan adalah B-Kompleks dan Injektamin, sedangkan obat-obatan yang digunakan adalah Kalbazen, Ivervet, Sulpidon dan Penstrep.

Total biaya bahan tidak langsung usaha penggemukan sapi potong mitra dan non mitra dapat dilihat pada Tabel 2.

\section{Biaya tidak langsung variabel lain}

Biaya tidak langsung variabel lain merupakan faktor produksi lain yang diperhitungkan ke dalam biaya tidak langsung. Beberapa faktor produksi lainnya adalah adalah biaya transportasi dan biaya listrik. Biaya tidak langsung variabel lain usaha penggemukan sapi potong mitra dan non mitra dapat dilihat pada Tabel 2 .

Total biaya yang dikeluarkan oleh usaha penggemukan sapi potong mitra untuk membayar bahan tidak langsung berupa pakan, vitamin, dan obat-obatan adalah sebesar Rp4.401.272,46 dan non mitra sebesar Rp4.255.580,17 dalam satu periode. Hal ini menunjukkan bahwa total biaya yang dikeluarkan oleh usaha penggemukan sapi potong mitra untuk membayar bahan tidak langsung lebih tinggi dibandingkan dengan biaya tidak langsung variabel lainnya. Hal ini sejalan dengan penelitian Hadi, Ismono, dan Yanfika (2015), biaya bahan tidak langsung menjadi biaya paling tinggi yang dikeluarkan dibandingkan biaya tidak langsung variabel lainnya.

Total biaya yang dikeluarkan oleh usaha penggemukan sapi potong mitra untuk membayar biaya tidak langsung variabel lain berupa biaya transportasi dan listrik adalah sebesar Rp102.893,78 dan non mitra sebesar Rp96.116,88 dalam satu periode. Hal ini menunjukkan bahwa total biaya yang dikeluarkan oleh usaha penggemukan sapi potong mitra untuk membayar biaya tidak langsung variabel lain lebih tinggi sebesar 7,05 persen daripada total biaya yang dikeluarkan oleh usaha penggemukan sapi potong mitra karena perbedaan lokasi saat membeli bakalan sapi mempengaruhi biaya transportasi yang dikeluarkan.

\section{Biaya tenaga kerja tak langsung}

Tenaga kerja tak langsung pada usaha penggemukan sapi potong adalah tenaga kerja yang tidak terlibat langsung dalam kegiatan penggemukan sapi potong seperti tenaga kerja yang membantu dalam proses penimbangan sapi yang berasal dari anggota Kelompok Ternak Limousin tetapi tidak terlibat langsung selama proses penggemukan sapi potong.

Total biaya yang dikeluarkan oleh usaha penggemukan sapi potong mitra untuk membayar tenaga kerja tak langsung adalah sebesar Rp11.355,31 dan non mitra sebesar Rp9.611,69 dalam satu periode. Hal ini menunjukkan bahwa total biaya yang dikeluarkan oleh usaha penggemukan sapi potong mitra untuk membayar tenaga kerja tak langsung lebih tinggi sebesar 18,14 persen daripada total biayayang dikeluarkan oleh usaha penggemukan sapi potong non-mitra karena jumlah tenaga kerja tidak langsung pada usaha penggemukan sapi potong mitra lebih banyak daripada non mitra yang mempengaruhi biaya tenaga kerja tak langsung yang dikeluarkan.

\section{Biaya tidak langsung tetap}

Biaya tidak langsung tetap merupakan biaya yang tidak berubah meskipun terjadi perubahan volume produksi. Biaya tidak langsung tetap terdiri dari pajak usaha, bunga dan biaya penyusutan dari semua peralatan.

1) Pajak

Total biaya pajak yang dibayarkan per periode oleh usaha penggemukan sapi potong mitra adalah sebesar Rp4.591,58 dan non mitra adalah sebesar Rp4.027,30. Hal ini menunjukkan bahwa total biaya yang dikeluarkan oleh usaha penggemukan sapi potong mitra untuk membayar pajak lebih tinggi sebesar 14,01 persen daripada total biaya yang dikeluarkan oleh usaha penggemukan sapi potong non mitra karena perbedaan luas kandang dan luas pekarangan rumah.

\section{2) Bunga}

Total biaya bunga dana tunai yang dikeluarkan usaha penggemukan sapi potong mitra selama satu periode sebesar Rp616.666,67 dan non mitra selama satu periode sebesar Rp618.992,70. Hal 
ini menunjukkan bahwa biaya rata-rata yang dikeluarkan oleh usaha penggemukan sapi potong non mitra untuk membayar bunga dana tunai lebih tinggi sebesar 0,37 persen daripada biaya rata-rata yang dikeluarkan oleh usaha penggemukan sapi potong mitra.

\section{3) Penyusutan Alat}

Peralatan yang digunakan oleh peternak responden adalah cangkul, sekop, garu, ember, suntikan, selang, sapu lidi dan angkong. Berikut biaya penyusutan kandang dan alat pada usaha penggemukan sapi potong mitra dan non mitra dapat dilihat pada Tabel 3.

Berdasarkan Tabel 3, terlihat total biaya penyusutan usaha penggemukan sapi potong mitra sebesar Rp250.386,71 dan usaha penggemukan sapi potong non-mitra sebesar Rp239.252,66 per periode. Total biaya yang dikeluarkan oleh usaha penggemukan sapi potong mitra untuk membayar biaya penyusutan lebih tinggi dibandingkan usaha penggemukan sapi potong non-mitra, karena perbedaan ukuran kandang dan peralatan yang digunakan mempengaruhi biaya penyusutan yang dikeluarkan. Hal ini sejalan dengan penelitian Anggraeni, Suryadi, dan Fitriani (2014), biaya penyusutan kandang akibat faktor bahan bangunan menjadi biaya paling tinggi yang dikeluarkan dibandingkan biaya penyusutan lainnya.

\section{Analisis Harga Pokok Produksi Usaha Penggemukan Sapi Potong}

Menurut Supriyono (2002), harga pokok produksi adalah aktiva atau jasa yang dikorbankan atau diserahkan dalam proses produksi. Perhitungan harga pokok produksi diperoleh dengan membagi total biaya produksi dengan jumlah produksi (bobot akhir sapi potong dewasa) dengan satuan $\mathrm{Rp} /$ kilogram. Perhitungan harga pokok produksi usaha penggemukan sapi potong mitra dan nonmitra di Desa Astomulyo Kecamatan Punggur Kabupaten Lampung Tengah dapat dilihat pada Tabel 4.

Berdasarkan Tabel 4, harga pokok produksi usaha penggemukan sapi potong mitra per periode adalah sebesar Rp39.119,17 per kilogram dan non mitra sebesar Rp40.552,24 per kilogram. Hal ini sejalan dengan penelitian Irasanti, Zakaria, dan Adawiyah (2019), yang menyatakan bahwa harga pokok produksi peternak mitra lebih rendah daripada peternak non mitra.
Tabel 3. Jumlah penggunaan alat dan nilai penyusutan usaha penggemukan sapi potong selama satu periode

\begin{tabular}{lrr}
\hline \multirow{2}{*}{$\begin{array}{c}\text { Nama } \\
\text { Peralatan }\end{array}$} & \multicolumn{1}{c}{$\begin{array}{c}\text { Mitra } \\
\text { Biaya Penyusutan } \\
\text { (Rp/periode) }\end{array}$} & $\begin{array}{c}\text { Biaya Penyusutan } \\
\text { (Rp/periode) }\end{array}$ \\
\hline Kandang & $179.993,76$ & $200.624,65$ \\
Cangkul & $3.844,20$ & $4.901,96$ \\
Sekop & $2.047,62$ & $1.960,78$ \\
Garu & $2.351,14$ & $2.265,67$ \\
Ember & $6.476,80$ & $7.426,63$ \\
Suntikan & $18.703,30$ & $17.185,70$ \\
Selang & $11.825,64$ & $12.270,28$ \\
Sapu lidi & $3.029,30$ & $5.670,90$ \\
Angkong & $22.796,34$ & $19.511,73$ \\
\hline Total Biaya & $250.386,71$ & $239.252,66$ \\
\hline
\end{tabular}

Perhitungan harga pokok produksi per kilogram ini diperoleh dengan menjumlahkan semua biaya produksi dalam satu periode sehingga diperoleh total biaya produksi yaitu sebesar Rp21.315.074,91 untuk usaha penggemukan sapi potong mitra dan non mitra sebesar Rp23.288.306,49, lalu membaginya dengan jumlah produksi dalam satu periode yaitu bobot akhir sapi potong dewasa adalah sebesar 544,88 kilogram untuk usaha penggemukan sapi potong mitra dan non mitra sebesar 574,28 kilogram.

Harga jual sapi potong pada usaha penggemukan sapi potong mitra dalam hitungan hidup per kilogram adalah sebesar Rp45.000,00 dan non mitra sebesar Rp45.000,00. Dengan demikian, dapat dilihat selisih antara harga jual dan harga pokok produksi dari perhitungan sebesar Rp5.880,83 untuk usaha penggemukan sapi potong mitra dan Rp4.447,75 untuk usaha penggemukan sapi potong non mitra sehingga usaha penggemukan sapi potong mitra dan nonmitra memperoleh laba karena harga pokok produksi lebih rendah dari harga jual yang berlaku. Hal ini sejalan dengan penelitian Kurniawati, Ismono, dan Sayekti (2014), yang menyatakan peternak memperoleh laba karena harga jual lebih tinggi dibandingkan harga pokok produksi per kilogram.

\section{Uji Beda}

Setelah dilakukan perhitungan besarnya harga pokok produksi usaha penggemukan sapi potong mitra dan non-mitra kemudian dilakukan uji beda (Independent Samples Test) menggunakan SPSS untuk melihat perbedaan yang signifikan antara harga pokok produksi usaha penggemukan sapi potong mitra dengan non-mitra. 
Tabel 4. Perhitungan harga pokok produksi usaha penggemukan sapi potong mitra dan non mitra per periode

\begin{tabular}{|c|c|c|c|c|c|c|}
\hline \multirow[t]{2}{*}{ No } & \multirow[t]{2}{*}{ Keterangan } & \multirow[t]{2}{*}{ Satuan } & \multicolumn{2}{|c|}{$\begin{array}{c}\text { Mitra } \\
\text { Usaha penggemukan sapi } \\
\text { potong mitra } 1 \text { ekor }\end{array}$} & \multicolumn{2}{|c|}{$\begin{array}{l}\text { Non mitra } \\
\text { Usaha penggemukan sapi } \\
\text { potong non mitra } 1 \text { ekor }\end{array}$} \\
\hline & & & Total & $\begin{array}{c}\text { Persentase } \\
(\%)\end{array}$ & Total & $\begin{array}{c}\text { Persentase } \\
(\%)\end{array}$ \\
\hline 1 & Jumlah produksi per periode & $\mathrm{Kg}$ & 544,88 & & 574,28 & \\
\hline 2 & Biaya bahan langsung per periode & $\mathrm{Rp}$ & $15.324 .769,23$ & 71,90 & $17.492 .733,56$ & 75,11 \\
\hline 3 & Biaya tenaga kerja langsung & $\mathrm{Rp}$ & $603.139,19$ & 2,83 & $571.991,54$ & 2,46 \\
\hline \multirow[t]{8}{*}{4} & Biaya tidak langsung variabel per periode & & 0,00 & & & \\
\hline & Biaya bahan tidak langsung & & 0,00 & & & \\
\hline & Pakan & $\mathrm{Rp}$ & 4.197.790,11 & 19,69 & $4.055 .720,88$ & 17,42 \\
\hline & Vitamin & $\mathrm{Rp}$ & $103.031,21$ & 0,48 & $100.991,93$ & 0,43 \\
\hline & Obat-obatan & $\mathrm{Rp}$ & $100.451,14$ & 0,47 & $98.867,36$ & 0,42 \\
\hline & Biaya transportasi & $\mathrm{Rp}$ & $75.421,25$ & 0,35 & $70.165,32$ & 0,30 \\
\hline & Biaya tenaga kerja tak langsung & $\mathrm{Rp}$ & $11.355,31$ & 0,05 & $9.611,69$ & 0,04 \\
\hline & Biaya listrik & $\mathrm{Rp}$ & $27.472,53$ & 0,13 & $25.951,56$ & 0,11 \\
\hline \multirow[t]{4}{*}{5} & Biaya tidak langsung tetap per periode & & & & & \\
\hline & Penyusutan & $\mathrm{Rp}$ & $250.386,71$ & 1,17 & $239.252,66$ & 1,03 \\
\hline & Pajak & $\mathrm{Rp}$ & $4.591,58$ & 0,02 & $4.027,30$ & 0,02 \\
\hline & Bunga & $\mathrm{Rp}$ & $616.666,67$ & 2,89 & $618.992,70$ & 2,66 \\
\hline 6 & Total Biaya & $\mathrm{Rp}$ & 21.315.074,91 & & $23.288 .306,49$ & \\
\hline 7 & Harga pokok produksi per kg & $\mathrm{Rp} / \mathrm{kg}$ & $39.119,17$ & & $40.552,24$ & \\
\hline 8 & Persentase & persen & & 100 & & 100 \\
\hline
\end{tabular}

Tabel 5. Perhitungan harga pokok penjualan usaha penggemukan sapi potong mitra dan non mitra per periode

\begin{tabular}{|c|c|c|c|c|c|c|}
\hline \multirow{3}{*}{ No } & \multirow{3}{*}{ Keterangan } & \multirow{3}{*}{ Satuan } & \multicolumn{2}{|c|}{ Mitra } & \multicolumn{2}{|c|}{ Non mitra } \\
\hline & & & \multicolumn{2}{|c|}{$\begin{array}{l}\text { Usaha penggemukan sapi } \\
\text { potong mitra } 1 \text { ekor }\end{array}$} & \multicolumn{2}{|c|}{$\begin{array}{l}\text { Usaha penggemukan sapi } \\
\text { potong non mitra } 1 \text { ekor }\end{array}$} \\
\hline & & & Total & $\begin{array}{l}\text { Persentase } \\
\text { (persen) }\end{array}$ & Total & $\begin{array}{l}\text { Persentase } \\
\text { (persen) }\end{array}$ \\
\hline 1 & Jumlah produksi per periode & $\mathrm{Kg}$ & 544,88 & & 574,28 & \\
\hline 2 & Harga pokok produksi & $\mathrm{Rp} / \mathrm{kg}$ & $39.119,17$ & 98,38 & $40.552,24$ & 99,55 \\
\hline \multirow[t]{3}{*}{3} & Biaya-biaya penjualan & & & & & \\
\hline & Biaya penimbangan sapi & $\mathrm{Rp} / \mathrm{kg}$ & 45,88 & 0,12 & 43,52 & 0,11 \\
\hline & Biaya perolehan keuntungan PT & $\mathrm{Rp} / \mathrm{kg}$ & 500,00 & 1,26 & 0,00 & 0 \\
\hline \multirow[t]{2}{*}{4} & Biaya administrasi dan umum & & & & & \\
\hline & Biaya telepon & $\mathrm{Rp} / \mathrm{kg}$ & 98,85 & 0,25 & 140,36 & 0,34 \\
\hline 5 & Harga pokok penjualan per $\mathrm{kg}$ & $\mathrm{Rp} / \mathrm{kg}$ & $39.763,90$ & & $40.736,12$ & \\
\hline 6 & Total persentase & Persen & & 100,00 & & 100,00 \\
\hline
\end{tabular}

Uji beda secara statistik menggunakan SPSS diketahui nilai Sig. (2-tailed) sebesar 0,009 <0,05, sesuai dengan dasar pengambilan keputusan dalam uji independent sample $t$ test dapat disimpulkan ada perbedaan signifikan harga pokok produksi antara usaha penggemukan sapi potong mitra dengan non-mitra

\section{Analisis Harga Pokok Penjualan Usaha Penggemukan Sapi Potong}

Menurut Adikoesoemah (1982), perhitungan harga pokok penjualan diperoleh dengan menjumlahkan harga pokok produksi, biaya-biaya penjualan dan biaya-biaya administrasi dan umum (Rp/kg). Harga pokok penjualan usaha penggemukan sapi potong mitra per periode adalah sebesar
Rp39.763,90 per kilogram dan non-mitra sebesar Rp40.736,12 per kilogram.

Perhitungan harga pokok penjualan per kilogram ini diperoleh dengan menjumlahkan harga pokok produksi yaitu sebesar Rp39.119,17 per kilogram untuk usaha penggemukan sapi potong mitra dan non-mitra sebesar Rp40.552,24 per kilogram lalu menambahnya dengan biaya-biaya penjualan dan

biaya administrasi dan umum yaitu biaya penimbangan sapi adalah sebesar Rp45,48 per kilogram. Biaya perolehan keuntungan PT adalah sebesar Rp500,00 per kilogram, dan biaya telepon adalah sebesar Rp98,85 per kilogram untuk usaha penggemukan sapi potong mitra dan biaya penimbangan sapi adalah sebesar Rp45,32 per kilogram dan biaya telepon per periode adalah 
sebesar Rp140,36 per kilogram untuk usaha penggemukan sapi potong non-mitra. Perhitungan harga pokok penjualan usaha penggemukan sapi potong mitra dan non mitra di Desa Astomulyo Kecamatan Punggur Kabupaten Lampung Tengah disajikan pada Tabel 5.

Selisih antara harga jual dan harga pokok penjualan dari perhitungan sebesar Rp5.236,10 untuk usaha penggemukan sapi potong mitra dan non mitra sebesar Rp4.263,88, sehingga dapat dikatakan bahwa usaha penggemukan sapi potong mitra memperoleh laba karena harga pokok penjualan lebih rendah daripada harga jual. Hal ini sejalan dengan penelitian Karina, Ismono, dan Nugraha (2015), yang menyatakan peternak memperoleh laba karena harga jual lebih tinggi dibandingkan harga pokok penjualan per kilogram.

\section{Uji Beda}

Setelah dilakukan perhitungan besarnya harga pokok penjualan usaha penggemukan sapi potong mitra dan non mitra kemudian dilakukan uji beda $\mathrm{t}$ (Independent Samples Test) menggunakan SPSS untuk melihat adakah perbedaan yang signifikan antara harga pokok penjualan usaha penggemukan sapi potong mitra dengan usaha penggemukan sapi potong non mitra.

Uji beda secara statistik menggunakan SPSS diketahui nilai Sig. (2-tailed) sebesar 0,037 <0,05, maka sesuai dengan dasar pengambilan keputusan dalam uji independent sample $t$ test dapat disimpulkan bahwa ada perbedaan yang signifikan harga pokok penjualan antara usaha penggemukan sapi potong mitra dengan non-mitra

\section{KESIMPULAN}

Harga pokok produksi usaha penggemukan sapi potong mitra dalam satu periode adalah sebesar Rp39.119,17/kg dan sebesar Rp40.552,24/kg untuk usaha penggemukan sapi potong non mitra. Harga pokok penjualan usaha penggemukan sapi potong mitra dalam satu periode adalah sebesar Rp39.763,90/kg dan sebesar Rp40.736,12/kg untuk usaha penggemukan sapi potong non mitra. Ada perbedaan yang signifikan harga pokok produksi dan harga pokok penjualan antara usaha penggemukan sapi potong mitra dan non mitra.

\section{DAFTAR PUSTAKA}

Anggraeni F, Suryadi D, dan Fitriani A. 2014.
Analisis harga pokok produksi dalam penetapan harga jual konsentrat (studi kasus di Unit Pengolahan Pakan Koperasi Peternakan Bandung Selatan (KPBS) Pangalengan Jawa Barat). Jurnal Unpad 3(4): 1-12.

http://jurnal.unpad.ac.id/ejournal/article/down load/4946/2519. [18 Juli 2020].

Adikoesoemah S. 1982. Cost Accounting (kalkulasi harga pokok), Edisi Pertama. Tarsito. Bandung.

BPS [Badan Pusat Statistik]. 2018. Data Statistik Indonesia. https://www.bps.go.id/. [26 April 2019]

Hadi AF, Ismono RH, dan Yanfika H. 2015. Analisis harga pokok produksi, laba usaha dan permintaan ayam ras pedaging probiotik di Kota Metro. Jurnal Ilmu Ilmu Agribisnis,, 3(3):

1-8.

http://jurnal.fp.unila.ac.id/index.php/JIA/articl e/view/1047. [20 Juni 2020].

Irasanti D, Zakaria WA, dan Adawiyah R. 2019. Analisis harga pokok produksi dan keuntungan usaha ternak ayam ras pedaging: studi kasus pada PT Cas di Kecamatan Bandar Mataram Kabupaten Lampung Tengah. Jurnal Ilmu Ilmu Agribisnis,, 4(1): 583-590. https://jurnal.fp.unila.ac.id/index.php/JIA/artic le/view/3876. [20 Juni 2020].

Kartadinata A. 2000. Akuntansi dan Analisis Biaya (Suatu Pendekatan Terhadap Tingkah Laku Biaya). Penerbit Rineka Cipta. Jakarta.

Karina A, Ismono RH, dan Nugraha A. 2015. Penentuan harga pokok produksi usaha penggemukan sapi (studi kasus usaha penggemukan sapi milik kastamar di Kecamatan Terbanggi Besar Kabupaten Lampung Tengah). Jurnal Ilmu Ilmu Agribisnis, $\quad 3(3)$ : 276-284. http://jurnal.fp.unila.ac.id/index.php/JIA/articl e/view/1052. [4 Agustus 2019].

Kurniawati N, Ismono RH, dan Sayekti WD. 2014. Analisis manajemen produksi dan penentuan harga pokok produksi (hpp) pada berbagai tingkat peternak ayam broiler. JURNAL ILMU ILMU AGRIBISNIS, 2(3): 232-238.

https://jurnal.fp.unila.ac.id/index.php/jia/articl e/view/805. [20 Juni 2020].

Supriyono. 2002. Akuntansi Biaya dan Akuntansi Manajemen Untuk Teknologi Maju dan Globalisasi. BPFE. Yogyakarta.

Yulianto P dan Saparinto C. 2010. Pembesaran Sapi Potong Secara Intensif. Penebar Swadaya. Jakarta. 